On Transfer Pricing

Conceptual Thoughts on the Nature of the Multinational Firm

Markus Brem

Thomas Tuch

W.P. No. 2005-11-03

November 2005

The main objective of the working paper series of the IIMA is to help faculty members, Research Staff and Doctoral Students to speedily share their research findings with professional colleagues, and to test out their research findings at the pre-publication stage

INDIAN INSTITUTE OF MANAGEMENT

AHMEDABAD-380 015

INDIA 


\title{
On Transfer Pricing Conceptual Thoughts on the Nature of the Multinational Firm
}

\author{
Markus Brem and Thomas Tucha ${ }^{\text {a) }}$
}

\begin{abstract}
This paper deploys Transaction Cost Economics (TCE) to elaborate on the shortcomings of "mainstream" transfer pricing in multinational firms. Departing from the notion that multinationals increasingly (re-)organize their business along multinational value chains irrespective of jurisdictional borders, the paper discusses the nature of the multinational firm and the problem of choosing the right intra-group (transfer) price. The mainstream transfer pricing approach derived from the Arm's Length Principle is deemed inappropriate for globalized MNEs. Referring to the value chain model, the paper suggests that "entrepreneurial coordination" is the key performance feature to be used for valuing business activity and for allocating - for tax transfer pricing purposes - standard markups and residual profits along the value chain.
\end{abstract}

Key Words: transfer pricing, value chain, transaction costs, multinational organization, entrepreneurial coordination

JEL: F23, L14, L22, M13

a) This paper represents work-in-progress and is an outcome from the research project "Measuring Valuable Transactions of Global Companies" funded by the KPMG/University of Illinois Business Measurement Research Program. We are grateful for its financial support of this research. All errors and mistakes in this paper are solely those of the authors. The usual disclaimers apply.

Contact: Markus Brem, visiting professor, Indian Institute of Management, Ahmedabad; permanent address: Wertingerstr. 40, 86368 Hirblingen, markus.brem@gmx.de;

Dipl.Vw. Thomas Tucha, Johann-Fichte-Str. 11,80805 München, ttucha@gmx.de 


\section{Introduction}

Cross-border business processes within the boundaries of multinational enterprises (MNEs) have significantly changed in the past two decades both in volume and in its contractual nature. The share of trade within the boundaries of MNEs is counting for up to three quarters of the total cross-border business between two countries (depending upon the countries). ${ }^{1}$ Besides this already enormous figure, more relevance of intra-group trade could be assumed if we had the statistics, especially with respect to the exchange of intangibles. ${ }^{2}$ Many of the intra-group transactions are often simply not priced because their exchange is coordinated through a different governance mechanism, i.e. within the organizational boundaries of the MNE.

In addition to the volume of intra-group trade, MNEs have significantly changed their way of doing business such as from 'a parent runs any distant foreign sourcing or distribution subsidiaries' into a more 'global organization operating multi-cultural, multi-national business lines and value chains'. The predominant structural element of large business organizations is increasingly the business line with its products and services generated throughout a value chain, rather than the legal entity. The restructuring and growth efforts of multinational firms including the voluminous M\&A waves and divestment projects indicate the ongoing changes of business organization. As a result, apart from legally required structures, an increasing share of international business is organized irrespective of national borders and legal corporate labels. Clear national "home state" affiliation is continuously replaced by globally integrated structures of functions, risks, and asset and their corresponding performance measurement units. Value drivers such as intellectual capital including the stakeholders' skills and tacit knowledge, nonhuman intangibles, and IT are difficult to allocate to either of the legal entities involved.

Given this picture of modern MNE business structures, transfer pricing has emerged to be key for coordinating business processes. By allocating incentives and income across the multinatinal's business units, transfer pricing refers to the management of global business organization ${ }^{3}$ and international (income) taxation. ${ }^{4}$

While no standard approach for management purposes has evolved to set transfer prices ex ante, in the tax-world (ex post) the Arm's Length Principle (ALP) is the internationally accepted benchmark. ${ }^{5}$ Interestingly, as our case studies indicate many of MNEs make use of one or the other Transfer Pricing Method (TPM), actually designed for tax purposes, to derive ex ante transfer prices with the consequence that the incentive features within the organization are distorted. In addition, an increasing criticism on the theoretical foundations and practical merits comes with the use of the ALP. ${ }^{6}$ In particular, one can argue that a too narrow, or even often inappropriate, interpretation of the ALP causes shortcomings in the mainstream transfer pricing

1 Neighbour 2002 (reporting up to 60\%). The OECD reports in its 2004 statistics (Intl.' Trade Report, 13 April 2005) that exports amount to US\$ 7.7 trillion and imports amount to US\$ 8.8 trillion within the OECD region. Some average figures estimate that about $40 \%$ of this trade volume is exchanged within the boundaries of multinational organizations.

2 No detailed information exists about trade within the boundaries of the multinational firm. Transactionspecific statistics on transfer pricing issues (e.g. prices, contractual features) is completely missing.

3 Smith (2002); Lambert (2001); Sansing (1999); Schjelderup/Sorgard (1997).

4 Przysuski (2005); Clavey (2003); Cloyd et al (2003); Marti et al. (2003); Boos (2002); Eden (1998); Pak/Zdanowicz (2001) report a U.S. federal income tax revenue loss in year 2000 of US\$ 44.55 billion because of over-invoiced imports and under-invoiced exports with respect to trade between related parties (Sec. 482 Internal Revenue Code). In its Transfer Pricing 2001 Global Survey, Ernst\&Young interviewed 638 parent corporations and 176 subsidiaries in 22 countries: 85\% of parents and 94\% of subsidiaries stated that transfer pricing is the most important tax issue for them. Among the interviewed parent companies, $52 \%$ in the US, $48 \%$ in UK, and $19 \%$ in Japan consider an APA in the future (because of higher legal certainty than with unsatisfying traditional approaches of income allocation, tax reporting, auditing, and litigation).

5 OECD (2001, 1995, 1979); Feinschreiber (2001); Eden (1998).

6 Brem (2004); European Commission (2001); Ring (2000); Radaelli (1997). 
approach and the corresponding use of TPM. ${ }^{7}$ For example, mainstream transfer pricing often does not reflect the facets of governing uncertainty, market size, internal knowledge, and incentives from residual income.

For us, the most obvious reason for this inadequacy of the mainstream approach in transfer pricing seems to be the discrepancy between the multilaterally value-adding business processes through various degrees of integrated multinational organizations versus the existing tax-world model of bilateral cross-border transactions which are deemed - according to this tax-world model - identifiable and, hence, separable from each other, and, hence, comparable with standalone firms. However, insights from organization theory tell a different story on the governance and pricing of intra-organizational transactions.

Though tax-world transfer pricing with its ex post nature of defending arm's length behaviour resorts, at least to some degree, to internationally practised standard procedures to value business processes (e.g. function and risk analysis; applying a certain TPM for the transaction type considered; identifying a corresponding set of comparables; establishing the interquartile Arm's Length Range; documentation), tax practitioners are in search of more sound concepts to allocate income in such a way that business economics of the underlying multi-functional value-adding processes is more accurately accounted for. ${ }^{8}$ For business-world transfer pricing with its ex ante nature, it is arguable to what extent transfer pricing should reflect arm's length features. However, notwithstanding the short-term possibilities to price below marginal costs, under longterm considerations each business is only sustainable if the unit stakeholders can expect a return on investment equal to, or above, opportunity costs of that investment. This said, a long-term business perspective of setting transfer pricing will show features of the ALP so that the organization can avoid the potential loss of its most valuable ${ }^{9}$ assets and stakeholders.

In other words, the appropriate use of the ALP making reference to governance and coordination differentials supports business transfer pricing. A simplified ALP approach is rarely taken by business-world transfer pricing: information and incentive structures inside a multinational organization are mostly - but not always - different from the ones governing transactions between independent actors. The result is obviously a pricing mechanism - and a remuneration value (e.g. price) - different from that used for third-party transactions.

If transfer pricing is considered by managerial decision-makers, then transfer prices placed by management decisions are most often intended to follow the tax-world requirements set forth in the ALP. Our experience shows that, in such situations, transfer prices are dictated by the tax departments of the MNE. Especially in the case of small and mid-sized MNEs, the costs incurred in maintaining two sets of books - one for business and one for tax purposes - often exceed the benefits (Hyde/Choe 2004) for which reason one set of accounts that is derived from the tax needs is deployed. And, in countries where tax accounting has to be in accordance with the commercial accounting principles, tax and business transfer pricing will be closely related to each other

7 Schneider (2003); Lev (2002); Plasschaert (2002); Oestreicher (2000); Vaysman (1996).

8 "One of the main difficulties in fulfilling the documentation requirements for transfer pricing is the determination of a comparable transaction (or company) at arm's length. This problem of finding arm's length comparables for valuing intra group transactions is not straightforward to solve. The trend towards more intra group transactions and fewer independent transactions, more complex group structures and the increased use of intangibles etc. has the effect of reducing the number of easily applicable clear comparables available to both business and tax administrations. Various ways have been suggested for tackling this question at EU level" (European Commission, 2001:348). The evolution of so-called advance ruling programmes for income allocation of multinational companies can be considered the immediate result of this inappropriateness and the discrepancy between tax-world and business-world transfer pricing, and the problem of finding an agreement as to how a certain transfer pricing case should be treated.

9 "valuable" in the sense of expectably profitable. 
anyway. ${ }^{10}$ Given the tendency for a "one-set of books" approach, the question on the design of appropriate transfer prices is not only a tax compliance issue of the MNE's tax department(s) but also a challenge for managerial decision makers.

Today's international tax-world of transfer pricing and income allocation relies on a narrow ALP concept. Given the governance difference between firms and markets (Coase, 1937; Williamson, 1975), it neglects fundamental insights from the theory of organization and governance. ${ }^{11}$ As a result, external transactions between independent parties and organization-internal transactions between dependent parties (related parties) are not distinguished from each other with respect to governance differentials. A simplified ALP approach lacks the power to grade organizationinternal transactions in accordance with the incurring governance features such as coordination, incentive, and safeguards. If the objectives are, however, that the transfer prices are supposed to properly address the incentives needs, the coordination, the control issues, and the income allocation, such grading becomes highly relevant.

This paper seeks to contribute to the discussion on how the next-generation of transfer pricing could look like. The core of the paper is on the problem of identifying entrepreneurial activity within the (multinational) organization with respect to coordination efforts subject to the institutional environment, the governance structure, and the dynamics of the firm. In other words, we consider "coordination" and "governance" of transactions as key features of value processes in an organization.

\section{2 "Mainstream" Transfer Pricing: Some Remarks}

Art. 9 of the OECD Model Tax Convention ${ }^{12}$ provides the basic principle, the so-called Arm's Length Principle (ALP), shaping tax transfer pricing. Art. 9 Section 1 reads as follows:

Where

a) an enterprise of a Contracting State participates directly or indirectly in the management, control or capital of an enterprise of the other Contracting State, or

b) the same persons participate directly or indirectly in the management, control or capital of an enterprise of a Contracting State and an enterprise of the other Contracting State,

and in either case conditions are made or imposed between the two enterprises in their commercial or financial relations which differ from those which would be made between independent enterprises, then any profits which would, but for those conditions, have accrued to one of the enterprises, but, by reason of those conditions, have not so accrued, may be included in the profits of that enterprise and taxed accordingly.

The ALP is built on the notion that income of a related party shall be the same as that of an unrelated party had the transaction(s) generating that income taken place between unrelated parties, given similar facts and circumstances. In other words, the ALP is sought to identify the tax base of a related party as if the relevant transactions were not organized within the multinational company but as between independent third parties. In practice, the ALP often is understood as the transfer price representing the same purpose as market price and, thus, should be on same size. What Art. 9 above however refers to are conditions determining the price. Consequently, it is the condition which is assumed to determine the price. Hence, if the pricing conditions of the organization-internal transaction differ from a comparable transaction between

10 Though, this becomes decreasingly relevant with the use of internationally used accounting standards (e.g. US GAAP, IAS).

11 With respect to economic theories, this narrow view of the ALP might be based on a traditional economic concept of the (multinational) firm as a production function.

12 Art. 9 OECD Model Tax Convention (OECD 1995a); OECD (2001). 
independent parties, the transfer price is expected to differ from the market price under the ALP perspective.

In other words, if the ALP is thought to survive the overwhelming increase of MNE in the real-life economy, the contractual distinction between markets and organization-internal transactions will have to be accounted for. Unfortunately, governance differentials are not reflected in most practical transfer pricing solutions. Also, the variance of contractual arrangements inside a large organization such as an MNE appears not to be reflected. Hence, we suggest that an extended view of transaction cost economics (TCE) and its links with more strategic approaches of management theory allow us to characterize the contractual and organizational difference between market transactions versus organization-internal transactions, and any hybrid form in between. ${ }^{13}$

\subsection{Transfer pricing}

The governance of transactions inside the MNE boundaries, either within the comparatively strong ties of "hierarchy" or by means of less strong governance mechanisms such as "hybrid" (e.g. networks, joint-ventures, franchising, related-party business), can be understood as the result of aligning the coordination to the appropriate incentive and control mechanism. The decision can be described as a trade-off behind the sum of transaction costs and production costs, relative to other possible governance forms. Similarly, an exchange via the market follows a transaction and production cost trade-off rationale which decision makers consider superior over organization-internal governance. Factors such as the relevant institutional environment (e.g. of a given country or a given region), the company's stage along a business or product cycle, transaction-specific features, and actor-specific behavioural attributes make up the transactional context and, hence, determine the contractual distance between two transaction partners.

Derived from such perspective, mainstream transfer pricing compares two governance settings which are actually not comparable (comp. Brem 2004):

(a) a (more or less well-identified) part of the multinational organization's total profit margin generated by more or less highly integrated business functions within the boundaries of the multinational company and "artificially" assigned through a legal focus of the firm to the legal entity (the tested party),

with

(b) the profit margins for transactions which have been coordinated in different sets of governance structures, i.e. profits which have been generated by organizationally independent enterprises (unrelated parties) operating in one institutional environment.

In other words, a simplified application of the ALP would compare a fraction of the MNE's profit with the profit of independent organizational units (third-party comparables), assuming that the tested party of the MNE represents a nexus of governance as the identified third-party comparables used to establish a benchmark, the so-called arm's length range of prices or profit margins. However, unless a transaction governed by the same transactional context can be found in the market, such an application of the ALP needs to be rejected for reasons that the determination of transfer price (or the profit margin) is inappropriate.

\subsection{Limited comparability}

Assuming that an appropriate application of the ALP has to reflect the transaction-specific governance structures, finding third-party comparables with comparable governance structures is at best a search of the needle in the haystack and at worst infeasible. Specific assets and unique entrepreneurial activity - often complementary with intangibles - may trigger hybrid or

13 Marti et al. (2003); Smith (2002); Lambert (2001); Oestreicher (2000); Sansing (1999); Schjelderup/Sorgard (1997); Meer-Kooistra (1994). 
hierarchical governance for which the vehicle "MNE" was chosen. ${ }^{14}$ And even they did exist, today's databases used for establishing an arm's length range do not contain information on the transactional context and attributes.

For example, direction, power, safeguarding, and enforcement are fundamental features of governance within the MNE which are likely to be very different if the same transaction was coordinated via the "market" of independent parties. Transfer pricing actually deals with MNEinternal transactions which are exchanged between functions such as: input sourcing, highcomplex manufacturing, distribution of final products and services, risk management (currency, warranty, guarantee, accounts receivable, etc.), the generation, provision and coordination of intellectual capital secured through formal property rights (e.g. trademarks, patents) as well as valuable intangibles not (yet) secured through non-formalized property rights (customs relationships, human capital skills, process knowledge, organizational knowledge, business perspectives, etc.). Even though, transactions related to such functions can be possibly identified in external markets, their governance will differ from firm-internal governance.

It is obvious that transactions (and its corresponding price) inside the MNE cannot be compared directly (price), and most often even not indirectly (margin), with a transaction between independent organizations. As a consequence, TPMs which require an external price or profit margin comparison are not applicable in most cases - though they are often used by national tax jurisdictions deploying the OECD model.

In mainstream practice, the so-called transaction-based methods comparing prices or margins are usually applied to very 'simple' transfer pricing cases with a considerably low deployment of intangible property and non-routine functions. However, the lack of comparable data on aspects which characterize the governance structure disfavours such methods using external comparisons. TCE would also claim that even the internal price comparison is not adequate because the transactional attributes are likely to be different between related-party transactions and independent-party transactions. ${ }^{15}$ Besides the tax-world shortcomings of direct price and/or margin comparison, incentive issues are likely to be misaligned if transfer prices are established on the notion of comparables from external markets.

However, even if direct or indirect comparisons were deemed to fit TCE, they would have to be classified infeasible because publicly available data on comparables do not provide sufficient information on the contractual specifics and the relevant transactional context. Databases used in mainstream transfer pricing simply refer to financial statements and provide limited description about the companies's activities. Transaction-based information is rarely provided by the databases used today. Price-related databases such as on interest rates do not usually include information on the transactional context under which the parties contracted.

Also, (transaction-based) price and profit margin comparisons lack information on case-specific fact patterns such as stage of market penetration, market fluctuation, any unique event (large risk damages), exchange rate variations, recession, inflation, etc. Actually, the same holds for the use of profit-based methods and profit level indicators. Thus, the comparability of a transaction, the business organization (functions, risks, assets), and the contractual structure is normally not given, burdening the issuance of any reliable statement on the appropriateness of the transfer price (direct comparison) or its related income stream (indirect comparison). On the other hand, mainstream transfer pricing does exactly deploy such comparisons - surprisingly with the accuracy of the second and - sometimes even - third digit after the percentage comma. In other

14 Oestreicher (2000); see also Schneider (2003).

15 This can be illustrated by a very simple example: suppose a bank lends money to an independent borrower who borrows from this bank for the first time. After having assessed the risk structure of this credit, the bank may wish to request an interest rate of, say, $10 \%$ which is assumed to cover operating expenses plus operating profit. Basically, a traditional ALP approach claims that an internal credit between related parties of the multinational firm should be priced in the same way. Apart from tax optimization objectives, differences in creditworthiness, for example, are rarely accounted for. 
words, the business-world reality and contractual complexity are rarely reflected in tax-world transfer pricing.

\subsection{Temporary solutions}

The deployment of profit-based TPM (e.g. Comparable Profit Method, CPM, and Profit Split Methods) with the use of profit level indicators (e.g. return on capital employed or certain financial ratios) and the determination of a "profit margin range" (normally the interquartile range) of identified arm's length comparables have been sought to bypass these shortcomings of the ALP. ${ }^{16}$ Profit-based TPMs compare the profit margin of the tested party (related party) with an interquartile range of corresponding profit margins of unrelated parties. Not the transactionbased margin but the company's profit margin is considered with the result that a CPM turns into a transaction-based Transactional Net Margin Method (TNMM) if the tested party only performs one related-party transaction. Generally, whether the ALP is met is then derived indirectly by the assessment as to whether the profit margin of the test party falls in the comparable benchmark range.

Like transaction-based TPMs, deploying profit-based TPMs for arm's length tests is limited by the availability of comparable data. Lacking any solution to this limited availability of comparable data in an international context, taxpayers and tax authorities spend incredible resources to identify comparable data, or to develop comparable data, for testing the related parties' margin or other profit level indicators in order to assess whether the taxpayer met the ALP. Notwithstanding the non-comparability problem (e.g. for value chain issues), while databases are fairly available in the US and Canada and various European countries, there is generally a huge lack of comparable data for transfer pricing purposes in other OECD countries and, even more importantly, in transition and emerging countries (China, India, Malaysia, Brazil, Russia), let aside the situation in developing countries. ${ }^{17}$

\subsection{Transfer pricing for highly integrated business processes}

The limitations to establish arm's length behaviour in accordance with mainstream transfer pricing can also be illustrated by means of the way global dealing cases are normally treated. With respect to international taxation, global dealing is deemed a business with highly integrated functions which cannot be unambiguously separated for purposes of determining an arm's length result. ${ }^{18}$ Generally, highly integrated functions and risk management characterize 24 -hour trading of derivatives and financial products within a multinational asset management company around the globe. ${ }^{19}$ Though there are legal separate entities, the transfer pricing community accepts that testing for arm's length results cannot be achieved on the basis of the separate-entity approach. Rather, allocating income from this type of highly integrated business processes can only be achieved by means of a modified profit-split approach, considering the firm as unitary entity.

16 Anglo-American countries have been deploying the CPM to the largest degree and later the OECD adopted this methodological approach in the 1995 OECD Guidelines. For the US, see Fouts (2001); Larsen et al. (2001); for Germany see Tucha (2002), Oestreicher and Vormoor (2004).

17 Normally, databases from the Bureau van Dijk (Amadeus, Jade, Fame), Disclosure (SEC, CanCorp, Worldscope), Moody's (Domestic, International), and Standard\&Poor's (CompuStat, Global Vantage) are not designed for transfer pricing purposes but for rating and other business measurement purposes. In particular, normally these databases do not show transaction-specific information and profit results (because they are only based on publicly available data, e.g., financial statements, which do not show results of individual transactions). Therefore, the data structure may not necessarily allow a reliable test on the basis of profit level indicators for which reason a more comprehensive model is needed (see Project II). See also Eden (2003) mentioning the limited applicability of commercial databases for transfer pricing analyses because of their data structure which does normally not show transactionrelated information.

18 OECD (2001, e.g., Sec.3.5; Sec. 4.82), Treas. Reg. 1.482-6, 1.482-8 of the US IRS.

19 For a case study, see Ross/Woodham (2001). 
The most common approach is the Residual Profit Split (RPS) method which shows basically three steps: (a) identification of routine and non-routine functions; (b) remuneration of routine functions with standard markups derived from third-party comparables; (c) allocation of the residual to non-routine functions on the basis of certain allocation factors. Because non-routine functions are thought of as where unique intangi+ble property is deployed, the residual is allocated to the entities where these non-routine functions are performed. The allocation method normally is based on multi-factor allocation formula ${ }^{20}$ and the residual profit part is considered to be non-comparable. ${ }^{21}$ Yet, what RPS approaches in transfer pricing lack is a model to derive the split factor for the allocation of residual income which itself depends on the valuation of functions performed.

In fact, many business processes show the characteristics of global dealing cases, whereas today's international transfer pricing and income allocation approaches do not yet correspond to these characteristics. Rather, they are based on a concept which, if at all, might have been appropriate until the early 1990s for solving the majority of transfer pricing cases.

\section{The Organization of Multinational Business}

One reason for the mess in mainstream transfer pricing is that it lacks a clear concept of what determines the choice for firm-internal versus firm-external governance structures - and the continuum in between. The tax transfer pricing approach, often merely practised unilaterally (from one country's perspective) with no bilateral perspective on both transaction partners, does not reflect price and profit differentials which are the result of governing transactional uncertainty, asset specificity, measurability issues, and factors of the institutional environment. Most practitioner transfer pricing analysis simplistically describes "routine" and "non-routine" functions, risks, and assets, and then allocates profits to the MNE's legal units on the basis of a third-party comparison. A (dynamic) theory which makes use of governance cost differentials is not in place - nor is it really practised according to our experience.

Though a function and risk analysis is employed by practitioners, it is normally of a descriptive nature and it rarely indicates comparable measures which assess the degree of such governance cost differentials. This applies for both "routine" and "non-routine" business. While a premium on a certain risk may reflect mainstream transfer pricing, no clear concept exists on how to identify and allocate the (residual) profit pie under a given structure of entrepreneurial uncertainty, asset specificity, frequency, or quality measuraebility. If non-routine functions are identified, residual profit is shared either through a percentage split or by means of factors such as relative wage sum, relative assets, and relative revenues. The degree of organizational embeddedness of a certain function into the MNE is not considered. In other words, the interesting question of what distinguishes the MNE from "stand-alone" companies is simply disregarded.

20 Often, factors are based on relative portions of assets, labour expenses, and sales. The relative importance of these factors has a huge impact on the income apportionment. In future, the "sales" factor may be considered increasingly important because without sales no revenues and consequently no chance for profits which can be allocated. Moreover, other factors are possible and might be considered even more important in near future (ratings, balanced scorecards, other non-financial performance measures, earnings per share, salary of high-skilled employees, productivity measures, etc.); see also Sliwka (2002); Kaplan/Norton (2001). So far, differences in productivities in countries involved as well as any factor controlling for environmental circumstances (inflation, recession, rapidly emerging markets) are not yet employed in approaches using profit-split methods. However, as the statistics on the Advance Pricing Program of the IRS shows, both the taxpayer and the tax authority are very creative in developing allocation formulas (IRS 2002).

21 The Residual Profit Split Method still lacks a coherent model of how to identify and value routine and non-routine business. 


\subsection{Value chains and transfer pricing}

A large (multinational) organization can be best described along various structural layers (comp. Figure 1): ${ }^{22}$

- Legal: legal entities (and branches) which refer to national jurisdictions

- Management and responsibility: the multinational firm and its individual business units (accounting units) which may differ from the legal entity structure

- Functions: activity cells performing tasks with degrees of entrepreneurship

- Value chains: business line processes along value chains (lines of product generation)

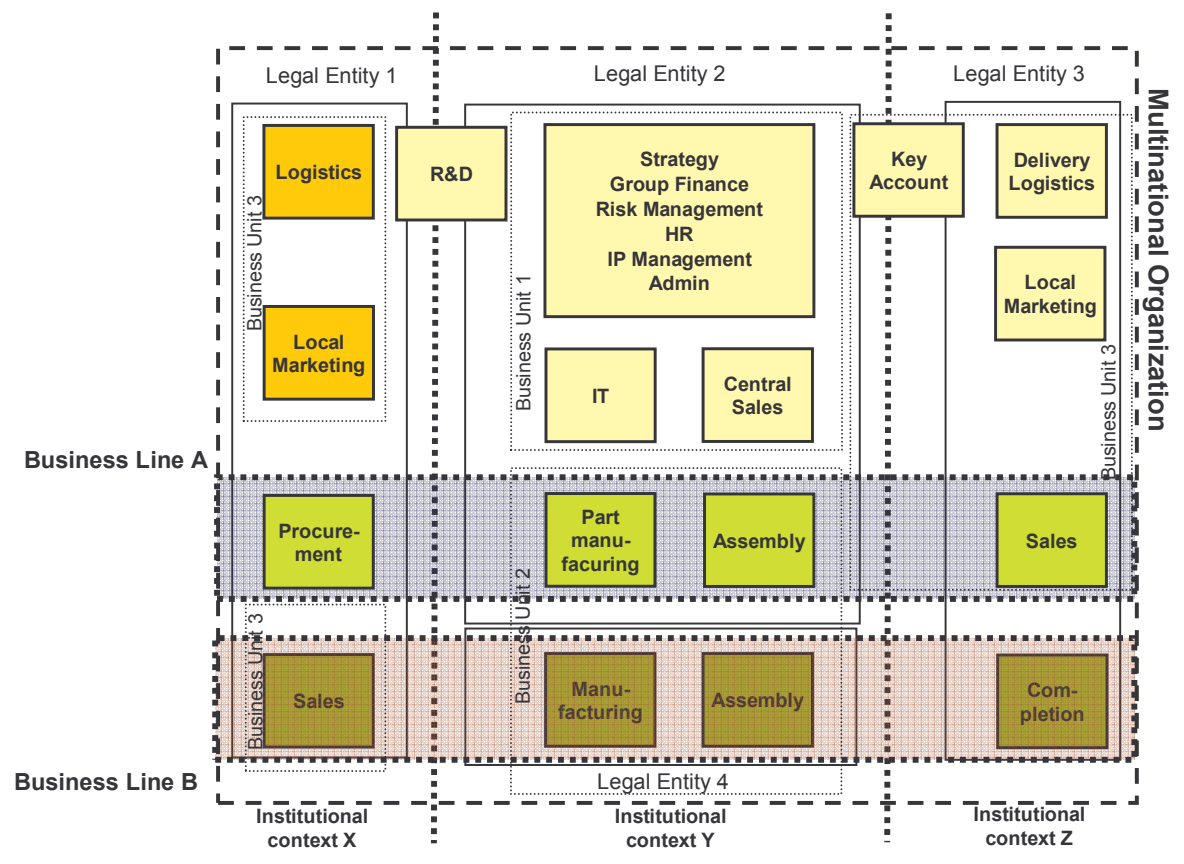

\section{Figure 1: $\quad$ Organization of MNE}

Figure 1 shows a multinational organization (multinational enterprise) with the layers "Legal Entity", "Business Unit", and "Business Line" (the value chains will be shown later). The example demonstrates four entities in three institutional contexts (e.g. three countries), three business units (e.g. Business Unit 1 as central strategy and services center; Business Unit 2 as manufacturing and assembly center; and Business 3 as sales and marketing center) and two business lines (here: A and B).

We hypothesize that, for transfer pricing purposes, the business line of a (multinational) firm is the core structural layer which shapes business operations. A business line consists of main functions which are part of the value chain (of single products or group of products). Support functions contribute with strategic coordination input, intangibles such as know-how, or key

22 We welcome feedback about other features which might be of relevance for transfer pricing. 
account activity, or simply support the value chains with services such as IT. Notwithstanding legal requirements in the jurisdictions where the MNE operates, the legal structure of the multinational organization turns out to be of minor relevance with respect to the business line's coordination aspects and value generation.

Note that the structural layer "business unit" can differ from the "business line" layer. The "business unit" often functions as a boundary of managerial, administrative, and control centres (e.g. cost or profit centres), whereas the "business line" is the operative perspective reflecting product and/or customer orientation. Some MNEs align their business units (accounting units such as cost centres or profit centres) to the business lines, others do not. If not, transfer pricing is not only of relevance because of tax base allocation to the taxpayer units (= legal entities) of the MNE but also to satisfy the needs to remunerate for business performance across accounting units. For example, in Figure 1 the business units 1, 2, and 3 intersect the business lines A and B, along which the value process is coordinated.

Two intermediate results can be derived from above:

1. Organizations operating in only one tax-jurisdiction do not have a transfer pricing system, if all structural layers of the organization are congruent. This situation is often observed in small firms. Likewise, if an organization operates in more than one tax jurisdiction, such (small) organization only requires a tax transfer pricing system.

2. As the organizational complexity increases, the number of structural layers and thus the number of transfer pricing systems increase. The multi-layer organization deploys more than one transfer pricing system. The number of transfer pricing systems used by an MNE depends upon the degree of incongruity between structural layers.

In other words, the distinction between business-world transfer pricing and tax-world transfer pricing becomes necessary in multinational organizations in which the business unit structure is different from the legal entity structure. Since advanced MNEs with a clear multinational and/or global focus have shifted their business organization from the legal entity structure, transfer pricing for such organizations is not only a tax issue but a daily battlesome business incentive and performance measurement issue topic. As shown in Figure 1, the multinational organization may have at least two transfer pricing systems in place (one for tax base allocation and one for business performance measurement between business units). It is also possible that such organization may also use a transfer pricing system inside its value chains and between the business lines.

\subsection{Value chains of the multinational group}

Given the organization focus above, a MNE can be described along its value chains which itself is structured into functions as smallest entrepreneurial activity cells (Figure 2). We consider that a value chain consists of several functional steps with functions/tasks performed, risk assumed, and assets deployed..$^{23}$ A given business unit may consist of one or more functional units contributing to one or more value chains. The term "function" can be referred to as the smallest activity cell between which transactions take place. Functions can be of a consecutive order (primary functions; example of Business Line in Figure 2: Strategy, Procurement, Part Manufacturing, Assembly, Sales) and of a supplementary order (support functions and/or strategic functions; example: Strategy, R\&D, IT, Central Sales, Key Account, Logistics, Marketing). Note that value chains can differ in terms of a small functional difference (e.g. the function Completion in Figure 2 is a part or not of the value chain in Business Line 1).

23 However, this is a rather legalistic view in which discrete transactions and boundaries of the functions can be identified (Freemann 1984; Porter 1995). More recent literature suggests that a "value chain is a series of interconnected firms < or functions, the authors $>$ engaged in bringing value to a good or service as the good or service makes its way to the end users" (Phillips and Caldwell, 2005). 


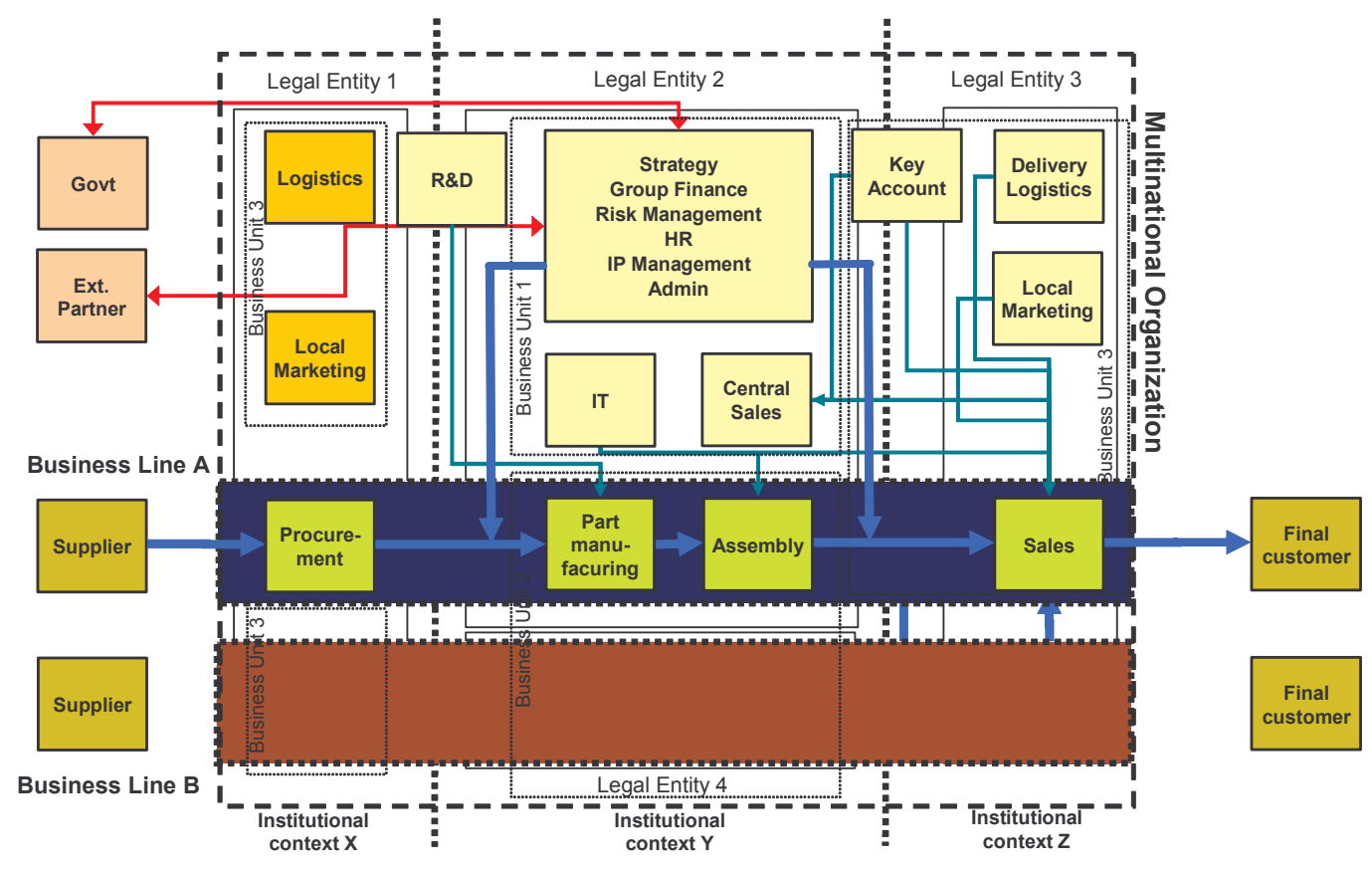

Figure 2: Transactional Flows in an MNE - a Simplified Model

Source: own presentation.

For descriptive transfer pricing purposes, the structure of the value chain, its starting and ending point within the MNE, and the key features of functional steps are of relevance. Note that MNEs rarely consist of only one linear value chain. Rather, several value chains embedded in each business line can make up the operative business of the MNE, and they can even intersect with each other. Also, not necessarily is it that each value chain coordinated inside an MNE necessarily fits exactly into the Business Line layer model.

With respect to the governance model, a transaction can be deemed hybrid - with apparently different governance issues involved than hierarchy or market - if this transaction crosses a business unit boundary. An example is a flow from Procurement to Part Manufacturing or from Assembly to Sales in Business Line A (Figure 2). Also, a flow from Completion (Business Line B) to Sales (Business Line A) could be called hybrid. Given the managerial layer (business unit structure), a transaction is hybrid even within the same legal entity if a business unit transfer is involved. On the other hand, a transaction within the same business unit can be of "hierarchical" nature independently of the legal layer, e.g. an exchange between Part Manufacturing and Assembly in Business Line A. The TCE rationale for such distinction is as follows: while the former type of exchange is coordinated through the management of two business units, the latter one is coordinated by decisions of one management authority. Viewing the management authority as coordination device, different management authorities - even inside the same multinational organization - result in different governance features and, hence, different transfer prices.

\subsection{Functions as "entrepreneurial cells"}

For transfer pricing purposes, the function can be understood as smallest activity cell (Figure 3). For each cell, process tasks such as input activity, transformation activity, and output activity have 
to be coordinated by the respective authority within the MNE. Given the description above, this authority is the business unit manager or, if an additional managerial layer exists within the business unit, the functional manager. For example, consider a value chain as provided in the illustrative example above. In the case of the procurement function, coordination issues refer to the purchase activities (input), intermediate storage and preparation tasks (transformation), and timely delivery/providing issues (output) of a good to be procured to the next functional step (here: $R \& D)$.

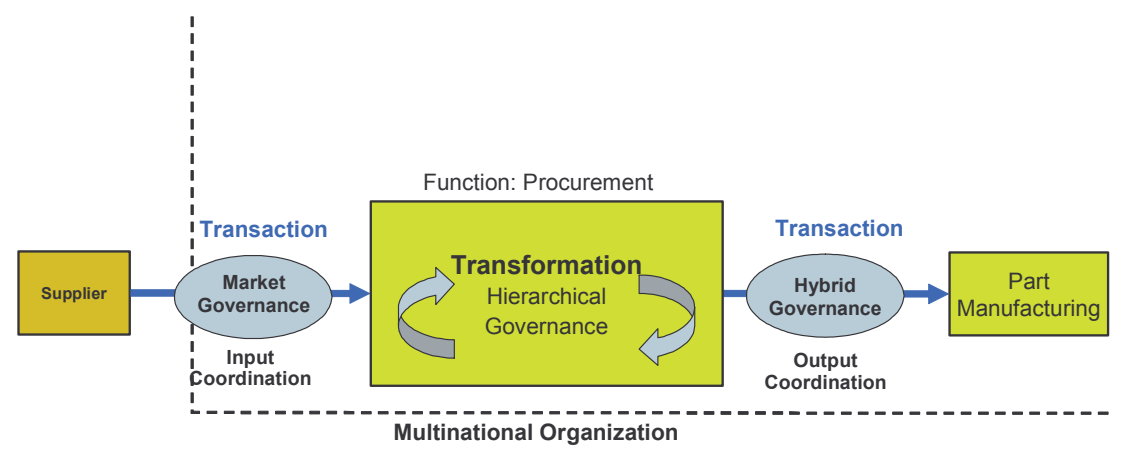

Figure 3: $\quad$ The Function as the Smallest Activity Cell

Source: own presentation.

With this concept, the value chain analysis generates information related to coordination aspects of input, transformation, and output activities at each functional step. As a definition, we assign

- the term "function" with 'activity', 'task', and 'operation', and

- the term "transaction" with 'exchange' between functional units. ${ }^{24}$

In most practical cases, fact-specific information about each individual function (cost data, internal policy information, etc.) is more likely to be available from the business unit level rather than the functional level. For transfer pricing purposes the functional unit can be characterized by attributes describing the governance features. We think that such characterization can be achieved through an index measurement system which makes reference to the individual functional cell and its embeddedness in, and the entrepreneurial contribution to, the value chain. In other words, transfer pricing is actually a function valuation problem. Given the layers of the multinational organization, such function valuation concept could depart from the nature of transactions governed inside the multinational organization.

24 We are aware that this definition does not fully comply with a strict TCE terminology which would claim that exchange by an hierarchical governance is also a "transaction". However, our definition was chosen to better address the transfer pricing discussion where the term "transaction" is more narrowly used for exchange between "parties" or functions (excluding the transactions inside the function). 


\section{The Mechanisms of Governance and the Multinational Organization}

Mainstream transfer pricing on the basis of the aforementioned simplified ALP perspective appears to disregard organization theory which differentiates between degrees of contractual arrangements along the two poles of "spot markets" and "hierarchy". Consequently, such an approach has its foundation in the notion that related-party transfer prices can be assessed against third-party comparables by means of describing their cost calculus and the profit margins. Contrarily, TCE provides the notion that the various forms of exchange (external, hybrid, integrated) may have different governance cost rationales and, hence, justify transfer prices which can clearly differ from market prices (or corresponding margins). ${ }^{25}$

A TCE perspective of the firm looks at the contractual distinction of governing transactions. ${ }^{26}$ The standard model distinguishes the "price mechanisms" and the "firm" as coordination mechanism. Features of (vertical) integration and governance are central themes of TCE with the notion of discrete choice of governance forms. ${ }^{27}$ Explanatory to governance choice are factors such as the degree of asset specificity, frequency, uncertainty, measurability, trust, and social and cultural aspects. $^{28}$ A TCE approach can explain that costs of using either governance form ("governance structure") depend upon the transaction costs inherent, relative to the other forms, to establish, conduct, safeguard, and enforce the transaction. ${ }^{29}$ Extended to this standard model, the choice of a governance form may depend upon characteristics such as credible commitments, trust between transaction partners, formal and informal institutions, etc.

As governance costs are subject to transactional attributes, the actors, and the institutional environment, some transactions are efficiently coordinated internally within the firm, while others are preferably coordinated externally, i.e. between a firm and another entity. Attributes of the transactional context determining governance costs can be numerous and examples are as follows:

- Asset specificity, transactional frequency, transactional uncertainty, and measurability of the transaction. (Among these, asset specificity, uncertainty and measurability are often considered most decisive factors for the governance choice).

- The institutional environment referring to the property rights regimes and other institutional factors (political stability in a country, court enforcement feasibility, etc).

- The individual human actors subject to their behaviour such as playing trustful versus opportunistic.

- External and/or internal shifts in the relative transaction cost structure triggering the need for reorganization of the boundaries: merger/demerger, in-/outsourcing and/or organizational learning processes.

\subsection{Apparatus}

TCE claims that there are costs of using either governance structure for exchanging transactions (Williamson, 1985). According to Williamson's approach of TCE, transactions are coordinated

25 This is supported by cases which reveal that transactional steps such as contacting, contracting, and enforcing result in governance cost gradients across various governance structures inside and outside the MNE.

26 The dynamic issues behind transfer pricing (e.g., the different stages of business cycles) will be referred to in a later paper; for evolutionary aspects of the firm, see Dosi/Malerba (2002); Rathe/Witt (2001); Witt (2000); Nooteboom (1997); Nelson/Winter (1982).

27 Coase (1937); Williamson (1975, 1985, 1996); Spulber (1999); Williamson invented the term "Governance Structure" for these discrete alternatives of exchanging transactions (spot-market, hybrid, hierarchy, bureaucracy).

28 For an overview, see Shirley and Menard (2005); Foss (2005); Williamson (2000).

29 Transaction costs can be defined as costs of establishing and maintaining property rights (Allen, 1991). These costs are often referred to as costs of searching (e.g., finding transaction partners), conducting (e.g. exchanging the transaction), safeguarding (e.g. ensuring delivery and payments), and enforcing (e.g. arbitration, litigation) the transaction. 
according to discrete governance choices such as hierarchy $(\mathrm{H})$, hybrid $(\mathrm{X})$ or market $(\mathrm{M})$. While there is continuity along the governance spectrum, the $\mathrm{H}, \mathrm{X}$, and $\mathrm{M}$ could be also paraphrased by the terms "firm", "hybrid network", and "market". In this taxonomy of TCE, transactions are coordinated either

- internally within the firm (within the same business unit) or

- in hybrid of closely or loosely coupled business units or

- externally on the so-called "spot market" where transaction partners do not pursue long-term relationships

Related-party transactions may follow the pattern of 'hybrid governance' with various degrees of contractual relatedness. For example, a hybrid governance form can be an organization of more or less loosely coupled parties (Weick 1982). The relationship of, and the inherent transactions between, centre structures of a multinational firm can be deemed hybrid, too, with the degrees of ownership, management, and business dependency (e.g. relative revenue share with the party). Also, franchising, joint-venture, and other long-term relationships without formal ownership rights and/or management control may constitute hybrid governance. Given the spectrum of hybrid governance, the contractual distance - and thus the difference between the market governance on the one hand, and the hierarchical governance, on the other - is case-specific for each transaction.

The apparatus of governance choice works as follows with respect to asset specificity (k) indicating the degree of safeguarding costs against opportunism of transaction partners after having invested in relation-specific assets (Williamson, 1990). A high $k$, i.e. a high level of relation-specific investments (e.g. investments which can feasibly not be redeployed in a different production process) requires a mechanism to safeguard the transaction between the supplier and the buyer against potential opportunistic behaviour. The mechanism favored by TCE for such safeguarding is hierarchy, $\mathrm{H}$, that is the (vertical) integration of either the next or the previous step along the value chain (or both). TCE claims that, if highly specific assets are important for a certain production, the governance form $\mathrm{H}$ is dominant over $\mathrm{X}$ and $\mathrm{M}$ because of the relative lower level of transaction costs. Contrarily, $\mathrm{M}(\mathrm{X})$ is the preferred governance form in the case of low (medium) asset specificity because this governance form trades off the economically rational safeguarding effort against opportunism of other transaction partners (Figure 4). The level of assumed transactions costs (= costs of using a governance mechanism for a given transaction) determines the choice of such exchange mechanism relative to others (e.g., firm $=\mathrm{H}$, network $=$ $\mathrm{X}$, market $=\mathrm{M}$ ).

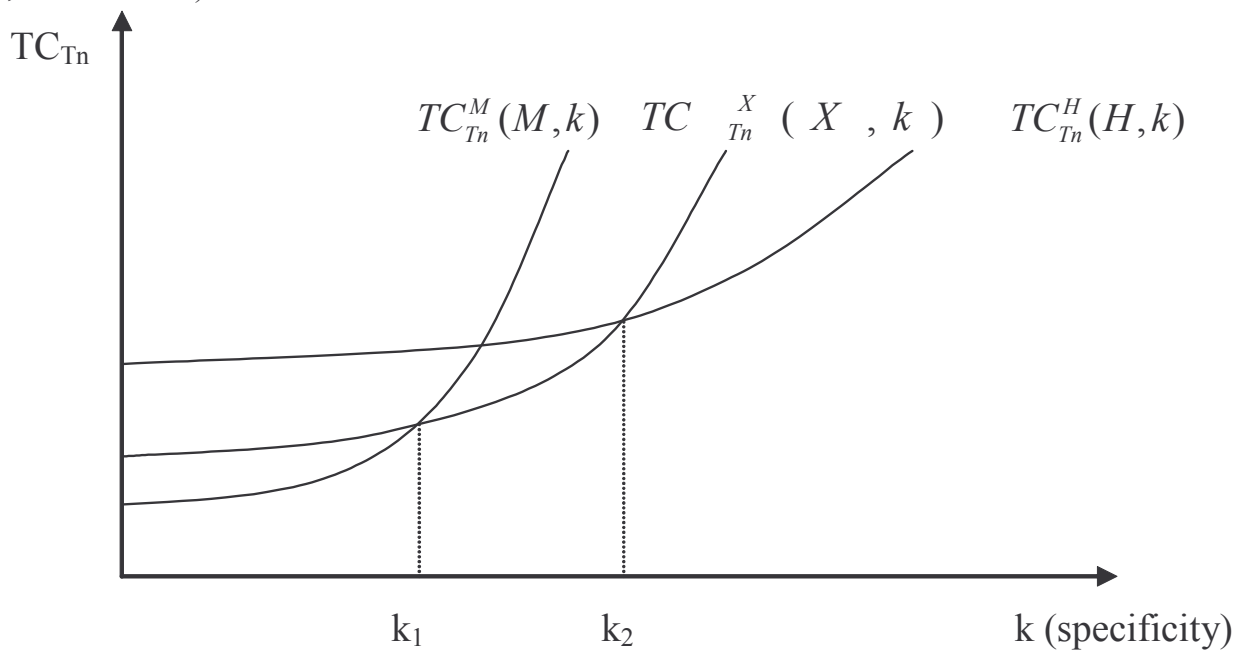

Figure 4: The Mechanism of Governance Choice

Source: Williamson (1990: 23). 
The most prevailing example for the hierarchical coordination mechanism of safeguarding against opportunistic behaviour is the firm. The one for the formal network might be the MNE with its related-party governance forms with mechanisms such as owernership, direction, or economic dependence. Also, networks without formal control rights can represent hybrid governance (e.g. franchising, joint-ventures, marketing efforts, associations) and, if analysed carefully, may even fall under the term "related-party" as used for transfer pricing purposes. Finally, the governance form "market" coordinates transactions between independent parties.

\subsection{Boundaries of the business unit and governance choice}

In a TCE perspective, the MNE - as any other multi-contractual organization - can be labelled as a coordination platform where many forms of governance structures are implemented with respect to internal and external transactions. In such a view, the economic boundaries of the MNE are not clear anymore: whether a certain transaction follows the market pricing mechanism or any form of internal pricing mechanism is probably not an either/or decision but rather a gradual one. Also, if one carefully investigates the inside business within multinational organizations, it may turn out that, what is labelled as related-party transaction, sometimes shows closer identity with market transactions other long-term external transactions. Table 1 classifies selected examples of coordination issues and contractual arrangements.

Table 1: Governance Forms for Selected Coordination Tasks of the MNE

\begin{tabular}{lcccc}
\hline \multicolumn{5}{c}{ Governance Forms } \\
\hline Market (M) & \multicolumn{2}{c}{ Hybrid (X) } & Firm (H) \\
\hline Contract R\&D & Joint-venture & $\begin{array}{c}\text { Contract R\&D } \\
\text { with specific } \\
\text { targets }\end{array}$ & $\begin{array}{c}\text { Internalized } \\
\text { R\&D }\end{array}$ \\
\hline Procurement & $\begin{array}{c}\text { Purchase of } \\
\text { standard raw } \\
\text { material }\end{array}$ & $\begin{array}{c}\text { Procurement of } \\
\text { high-quality } \\
\text { input }\end{array}$ & $\begin{array}{c}\text { Supply-chain } \\
\text { logistics with } \\
\text { one coordinator }\end{array}$ & Self-supply \\
\hline $\begin{array}{l}\text { Ownership of } \\
\text { capital }\end{array}$ & External & $\begin{array}{c}\text { Membership } \\
\text { Management }\end{array}$ & Shareholder & Manager-owned \\
\hline Labor & External & Cooperation & $\begin{array}{c}\text { Directive or } \\
\text { Negotiation }\end{array}$ & Internal \\
\hline & & & Internal & Internal \\
\hline
\end{tabular}

\section{Perspectives for Tomorrow's Transfer Pricing Approaches}

We assume that it is simply a matter of time when mainstream transfer pricing will undergo significant changes. Given the scope, scale, and nature of international business within MNEs, the old model of transfer pricing established in the 1960s and developed for mass application in the late 1980s/early 1990s may not fit in to the business world reality of today and the future. We expect that such changes are being driven by both the tax-world and the business-world needs for rethinking transfer pricing in accordance with an appropriate theory of the multinational business organization. Such theory may align governance and transaction costs with strategic management perspectives such as incentive design, control, internal bureaucracy, and ex ante and ex post income allocation. We discussed selected aspects of such theory, with the intention to explore aspects of the nature of the multinational firm which we are experiencing to be organized along value chains, business lines, business units, and legal entity layers. 
Given the globalization of MNE and the value chain organization of global business processes, the next generation of transfer pricing is likely to show characteristics which are different from a simplified application of the Arm's Length Principle. Our concept derives from the notion that external comparisons in transfer pricing cannot be achieved owing to a lack of comparable information which would be required for testing arm's length behavior.

Notwithstanding legal definitions, transactions of the MNE are rarely of an "either-or" feature (either "market" or "hierarchy"). Rather, whether a transaction shows the characteristics of an hierarchical transaction, a related-party transaction, or a market transaction depends upon various attributes of such transaction. These attributes determine the relative functional value generated by the transaction. Thus, the price of such transaction can be assessed by variables describing the institutional and economic context, the transaction-specific contract, the stage of the business process involved, the strategy chosen, and the function pattern (function, risk, assets).

As a consequence, comparable information on these specifics from third parties is rarely found in databases which provide company information. The more non-routine functions and intangibles are involved, the less is the tested function (or business unit) comparable with companies from external databases. Under these data constraints on comparables, the arm's length tests on transfer pricing will have to resort to internal information if the ALP is intended to remain viable.

We expect that a next-generation transfer pricing approach will - may have to - make use of patterns of governance to characterize and to value the functional contributions to the the overall value chain. These governance patterns are likely to serve for the design and/or establishment of arm's length behaviour inside the MNE. Given the governance pattern of (related-party) transactions, value chain analysis with risk-averse markups on routine functions and residual profit split remuneration for non-routine functions is likely to replace today's bilateral transfer pricing approach. 


\section{References}

Allen, D.W. (1991), What are Transaction Costs?. Research in Law and Economics 14, 1-18.

Bamford, Jim, and Ernst, David (2002), Measuring Alliance Performance. McKinsey on Finance (Autumn 2002), McKinsey.

Baistrocchi, Eduardo (2004), The Arm's-Length Standard in the $21^{\text {st }}$ Century: A Proposal for both Developed and Developing Countries. Tax Notes International: 241-255.

Baldenius, Tim, and Reichelstein; Stefan (2005), Exernal and Internal Pricing in Multidivisional Firms. Journal of Accounting Research, forthcoming.

Bastian, Nicole (2005), Divisional Performance Measurement and Transfer Pricing for Intangible Assets. Working Paper, Graduate School of Business, Stanford University.

Benito, Gabriel R.G. (2005), Divestment and International Business Strategy. Journal of Economic Geography, 5: 235-51.

Boot, W. A. Arnoud, Milbourn, Todd T. and Schmeits, Anjolein (2004), Credit Ratings as Coordination Mechanisms. SSRN Working Paper, University of Arizona.

Brem, Markus (2004), A New Approach to Transfer Pricing for Multinational Corporations. Tax Notes International, 33(11): 1005-15.

Clavey, C. (2003), Transfer Pricing in Selected Eurasian States. Tax Notes International, 29(3): 315-318.

Cloyd, C.B., Mills, L.F., and Weaver, C.D. (2003), Firm Valuation Effects of the Expatriation of U.S. Corporations to Tax Haven Countries. International and Comparative Tax, 3(1), Jan. 17, 2003.

Coase, R.H. (1937), The Nature of the Firm. Economica, 4: 386-405; reprinted in: Buckley, P.J., and J. Michie (eds.,) (1996), Firms, Organizations, and Contracts. New York: Oxford University Press.

Cortazar, Gonzalo, Schwartz, Eduardo S., and Naranjo, Lorenzo (2004), Term Structure Estimation in Low-Frequency Transaction Markets: A Kalman Filter Approach with Incomplete Panel-Data. SSRN Working Paper, University of California, Los Angeles, Finance Area.

Dosi, G. and Malerba, F. (2002), Interpreting Industrial Dynamics Twenty Years after Nelson and Winter's Evolutionary Theory of Economic Change: A Preface. Industrial and Corporate Change, 11(4): 619-22.

Eden, L. (1998), Taxing Multinationals: Transfer Pricing and Corporate Income Taxation in North America. Toronto: University of Toronto Press.

Eden, L. (2003), The Internalization Benefits of Transfer Price Manipulation. mimeo.

EU (2001), Towards an Internal Market Without Tax Obstacles. $\operatorname{COM(2001)~} 582$ final, http://europa.eu.int/comm/taxation_customs/publications/official_doc/IP/ip1468/commu nication_en.pdf

Feinschreiber, R. (2001), Transfer Pricing Handbook. Vols. 1 and 2, New York: John Wiley \& Sons.

Fouts, P.A. (2001), Economics of the Comparable Profits Method, in: Feinschreiber, R. (ed.), Transfer Pricing Handbook. Vols. 1 and 2, New York: John Wiley \& Sons. Chapter 23.

Freeman, R. Edward (1984). Strategic Management: A Stakeholder Approach. Boston: Pitman Publishing.

Göx, Robert F. and Schöndube, Jens Robert (2004), Strategic Transfer Pricing with Risk-Averse Agents. Schmalenbach Business Review, 56: 98-118. 
Hyde, Charles E., and Choe, Chongwoo (2004), Keeping Two Sets of Books: The Relationship between Tax and Incentive Transfer Prices. SSRN Working Paper; University of Arizona.

Kahle, Kathleen M. and Shastri, Kuldeep (2004), Firm Performance, Capital Structure and the Tax Benefits of Employee Stock Options. SSRN Working Paper, University of Arizona.

Kaplan, R.S. and Norton, D.P. (2001), The Strategy-Focused Organization: How Balanced Scorecard Companies Thrive in the New Business Environment. Boston: Harvard Business School Press.

Lambert, R.A. (2001), Contracting Theory and Accounting. Journal of Accounting and Economics, 32(1-3): 3-87.

Larson, C.R., Karayannis, M., and Burgess, J. (2001), Comparability Adjustments in Transfer Pricing, in: Feinschreiber, R. (ed.), Transfer Pricing Handbook. Vos. 1 and 2, New York: John Wiley \& Sons. Chapter 35.

Lengsfeld, Stephan (2005), Verrechnungspreise und Organisationsstrukturen in multinationalen Unternehmen - Zum Erkenntnisstand formaltheoretischer Analysen. Betriebswirtschaftliche Forschung und Praxis, 57(2): 137-55.

Marti, A., Schmid, S., and Lardelli, R. (2003), Switzerland's Informal Transfer Pricing Regime. Tax Notes International, 29(2): 183-187.

Meer-Kooistra, J. van der (1994), The Coordination of Internal Transactions: The Functioning of Transfer Pricing Systems in the Organizational Context. Management Accouting Research 2(4): 123.

Meer-Kooistra, J. van der (2004), A Model for Making Qualitative Transfer Pricing Adjustments. Working Paper, Faculty of Management and Organization, University of Groeningen.

Menard, Claude, and Mary Shirley (2005), Handbook of New Institutional Economics. New York: Springer.

Mills, Lillian F. and Newberry Kaye J. (2003), Do Foreign Multinationals' Tax Incentives Influence their U.S. Income Reporting and Debt Policy?. SSRN Working Paper, University of Arizona.

Morrison, Catherine J. (1992), A Microeconomic Approach to the Measurement of Economic Performance: Productivity Growth, Capacity Utilization, and Related Performance Indicators. New York: Springer-Verlag Press.

Neighbour, J. (2002), Transfer Pricing: Keeping it at Arm's Length. OECD Centre for Tax Policy and Administration, http://www.oecdobserver.org/ .

Nelson, R.R. and Winter, S.G. (1982), An Evolutionary Theory of Economic Change. Cambridge: The Belknap Press of Harvard University Press.

Nooteboom, Bart (1997), Path Dependence of Knowledge: Implications for the Theory of the Firm, in: Magnusson, L. and J. Ottosson (eds.), Evolutionary Economics and Path Dependence, Cheltenham: Edward Elgar Publishing, 57-78.

OECD (1979), Transfer Pricing and Multinational Enterprises. Three Taxation Issues, Reports of the OECD Committee on Fiscal Affairs. Paris.

OECD (ed., 1995), Transfer Pricing Guidelines for Multinational Enterprises and Tax Administrations. Parts I and II, Paris.

OECD (ed., 2001) Measuring Globalisation: The Role of Multinationals in OECD Economies. Paris.

Oestreicher, A. (2000), Konzern-Gewinnabgrenzung. München: Beck.

Oestreicher Andreas, and Vormoor, Christoph (2004), Verrechnungspreise mit Hilfe von Datenbanken - Vergleichbarkeit und Datenlage. Internationales Steuerrecht, 2: 95. 
Pak, S.J., and J.S. Zdanowicz (2001), U.S. Trade with the World: an Estimate of 2000 Lost U.S. Federal Income Tax Revenue due to Over-Invoiced Imports and Under-Invoiced Exports. Summary Report, Center for Banking and Financial Institutions. Florida International University, Miami.

Plasschaert, S. (2002), The EU Consolidated Income Tax Revisited. CESifo Working Paper No. 670(1), http://ssrn.com/abstract id=303704.

Phillips, Robert and Craig B. Caldwell (2005), Value Chain Responsibility: A Farewell to the Arm`s Length. Business and Society Review, 110(4), forthcoming.

Porter, Michael (1995), Competitive Advantage: Creating and Sustaining Superior Performance. New York: The Free Press.

Przysuski, Martin (2005). Transfer Pricing in India. Tax Planning International Transfer Pricing, August.

Radaelli, C.M. (1997), The Politics of Corporate Taxation in the European Union: Knowledge and International Policy Agenda, London: Routledge.

Rathe, K. and U. Witt, (2001), The Nature of the Firm: Static versus Developmental Interpretations. Journal of Management and Governance, 5(3-4): 331-51.

Sansing, R.C. (1999), Relationship-Specific Investments and the Transfer Pricing Paradox. Review of Accounting Studies, 4(2): 119-34.

Schjelderup, G., and L. Sorgard (1997), Transfer Pricing as a Strategic Device for Decentralized Multinationals. International Tax and Public Finance, 4(3): 277-90.

Schneider, D. (2003), Wider Marktpreise als Verrechnungspreise in der Besteuerung internationaler Kozerne, Der Betrieb, 56(2): 53-58.

Sliwka, D. (2002), On the Use of Nonfinancial Performance Measures in Management Compensation, Journal of Economics and Management Strategy, 11 (3): 487-511.

Smith, Michael (2002), Tax and Incentive Trade-Offs in Multinational Transfer Pricing. Journal of Accounting, Auditing and Finance, 17(3): 209-36.

Spulber, D. (1999), Market Microstructure: Intermediaries and the Theory of the Firm. Cambridge: Cambridge University Press.

Tucha, Thomas (2002), Der Einsatz von Unternehmensdatenbanken bei Verrechnungspreisanalysen. Internationales Steuerrecht, 21: 745-752.

Vaysman, I. (1996), A Model of Cost-Based Transfer Pricing. Review of Accounting Studies, 1(1): 73-108.

Weick, K. E. (1982) Management of Organizational Change among Loosely Coupled Elements, in: P.S. Goodmann (ed.), Change in Organizations. San Francisco: Jossey-Bass, 375408.

Williamson, O.E. (1975), Markets and Hierarchies: Analysis and Antitrust Implications. New York: Free Press.

Williamson, O.E. (1985), The Economic Institutions of Capitalism. London. New York: MacMillan.

Williamson, O.E. (1990), The Firm as a Nexus of Treaties: An Introduction, in Aoki, M., Gustafsson, B. and Williamson, O.E. (eds.), The Firm as a Nexus of Treaties. London: Sage Publications, 1-25. 